\title{
LA-5391-MS
}

INFORMAL REPORT

\section{Diffraction from \\ Circular and Irregular Apertures}


This report was prepared as an account of work sponsored by the United States Governmerst. Neither the United States nor the United States Atomic Energy Commission, nor any of their employees, nor any of their contractors, subcortractors, or their employees, makes any warraniv. express or im. plitd, of assumes any legai liability or responsibility for the accuracy, cum. pleteness or usefulness of any information, apparatus, product or process disclosed, or represents that its use would not intringe privately owned rights.

In the interest of promp: distribution, this LAMS re. port was not edited by the Technical Information r:alf.

Printed in the United States of America. Available from National Technical information Service

U. S. Department of Commerce 5285 Port Royal Road

Springfieid. Virginia 22151

Price: Printed Copy \$4.00: Microfiche 50.95 
LA.5391-MS

Informal Report

UC.34

ISSUED: Ortober 1973

Diffraction from

\title{
Circular and Irregular Apertures
}

\author{
by
}

O. P. Judd

\begin{abstract}
This report wo preperted an accouns of wonth

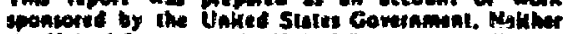

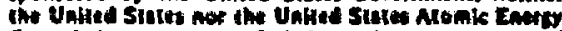

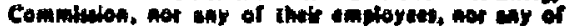

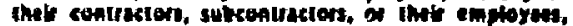

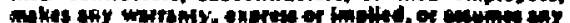

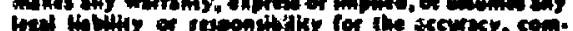

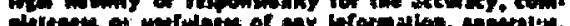
miran or a

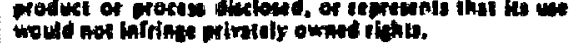

Motice 


\section{Intnodverion}

Thu diffection patcems ortglnatiog froa uniforaly diluatnated circular apertures ara vell hnown. The far field or Frauthofer region can be obtained in the fload for Atry pactern solution. In the near fluld or Preanel regtion in which the Fresnel numbar $\|$ > 2, the spacial deffraction pectern is obcatned by numarleal solution of Haxwell' equatons. The reaulce of ehis calculation in the Fresnet region thow the extatence of a zarge interofty peak ot the center of the diffraction pacearn for aven values of $\boldsymbol{H}$. The decriented effect of such high power Intenatr; pasks a a source of self-focupting in nolid-sece lasers he been enphasized previourly. It it therefore deatrable to reduce the anplicude of these diffraction "spikest or elfelnate then compleze1y.

The lerge anplizude of the central diffraction opthe reculte from the elreular symetry of the sparcure. Daviations from ctreular aymetry should reduse shis incenvicy peats constderab2y. Thie note is

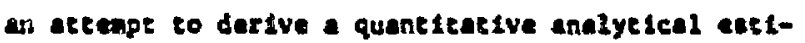
ate of tho central peak intensity as tunetion of apercure treegulertiy, To do thie, the problex has bets epprosched in serm of the kirchoff Integral formulation of diffracelon theory rather than eolucion of the parexial wave equation. Analytic expresatons appeared to be ore readily dersved with the former achod.

The baste cosweption of this wethod as applited in th1e note are the usual ones of scalar veraus vector diffraction cheory, the aperture radlut a is wuch largar than the vavelengeh, and thet the disence from the aperture $x_{0}$ is sufficienty large that $a^{2} / r_{0}{ }^{2}$ \& 2 . These condit lons are adequetely atiofled for sos practicel altustione of interest. The Kirchoff incegral formulation therefonit appeses to be a povezful aethod for treating diffraction problawe where anslyele golutione ere deelind. The apeeifle problen that is solved here is the on-axis incenstey reauleing fron a (1) untfotzly 11luminated sperzure (phase and aplicude), ard (2) Gausedian 11luntnation. The aperture is approxisazo1y cizcular with some andl irregulerfity abost an average redius. Excennion of the theory to inilude Cinte vovefrons curvature and spacinl bean divergance of the 11lualnation source to etralgheforvatd. (1) The theory any also be cppllcable to fupered spertures which includs bocls phese and amplicute variactons.

The resulte of ehis anulyais indicate that olentfteant "swoothing" of the on-axts Intensity peak ean be obteined for $\mathrm{H} \geq 20$ by datroductes percurbations ot the perdphezy of the apeztuze with an saplitude of $\approx .1 \mathrm{l}$. The grearer the degree of $17-$ regularkey, the greater is the anookhing. Irregular epereureo of this typa can be exally tabrtested and represent a siaple eathod of reducting the spatifl variations in intenaty introdued by diffracelon on apertured opeleal besm.

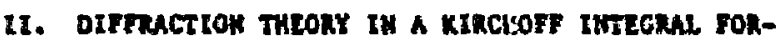
MUtheTION

Consider an erblerery spazture with an intenefzy diecribueton $F(0,6)$. The datenatey at the obeervation polne $P^{\prime}$ with polar coordtaces $w$ and 6 1s obeafned by walne the conezibuetons frow sach point o and a in the aptzeure. The geowery of the probles is shom in Fig. 1. The glectric fleld ot Ft Ia juat

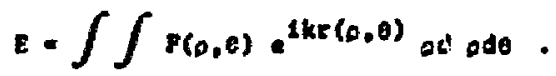




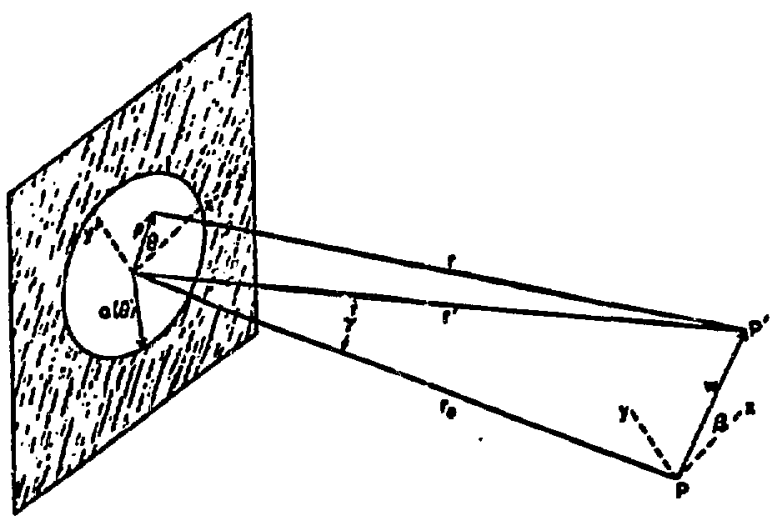

E1g. 1. Configuration and nosenclature for the diffraction problea.

The gecontzy of the problee gives

$$
\begin{aligned}
& r^{2}=\left(x-x^{1}\right)^{2}+\left(y-y^{\prime}\right)^{2}+r_{0}^{2} \\
& z^{12}=x^{12}+y^{12}+z_{0}^{2}
\end{aligned}
$$

where $r_{0}$ is the perpendicular distance from the plene of the aperture to the plane of observaties. Fron E1g. 1 and Eqs. (2) and (3), one obeater

$$
r=r^{\prime}\left[1+\frac{p^{2}}{r^{2}}-2 \rho \frac{u \cos (\theta+\beta)}{r^{12}}\right]^{\frac{1}{2}} \text {. }
$$

We now asaume that $p^{2} / r^{\circ 2}$ and $p w / x^{\circ 2}$ are 1 so that Eq. (6) becones to $O\left(0^{2} / x^{12}\right)$

$$
r-z^{\prime}+\frac{a^{2}}{2 x_{0}} \cos \gamma-\operatorname{asc} y \cos (\theta+B)
$$

where we have used the relation thet $z_{0}$ " $\tau^{\prime}$ cosr and $w=r^{\prime}$ einy. The point of obzervation lo spec1fied completely by the angles $\gamma$ and $B$. For sxial symetry, osly $Y$ neede to opecified.

The field as given by En. (1) can now bo wito ten in the forg

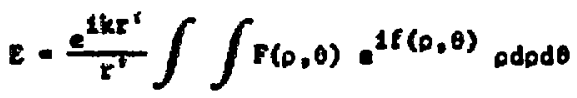

Here

$$
f(0, \theta)=\frac{k_{0}^{2}}{2 \tau_{0}} \cos y-k_{D} \sin y \cos (g+\theta) \text {. }
$$

Equ. (6) and (7) are the vorkins equetions of thls section and have been dertivad eicenhere ${ }^{(1)}$ by $*$ sintler wethod. For the tele belng, we will sesuse undfor 11 undration of the sperture so that $I(0,0)$ is watey. For conventence, we will alse drop the propugation factor $1 \mathrm{kx}^{\prime \prime} \mathrm{f}$ ' and reinetrt dt when needed.

Ualat the Gused funetion Ideasity,

$$
e^{\operatorname{stan} \theta}-\sum_{n} J_{n}(r) e^{\ln \theta}
$$

Eqe. (6) and (7) can also be wriceen in the form

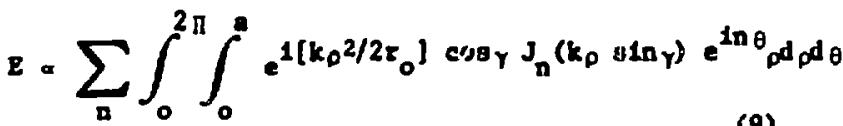

where a 18 the aperture radius which in general 1s a function of $\theta$.

\section{ERAUNHOEER DIFPRACTION}

In order to check the val1dity of $\mathrm{E}(7$. (9), we look for the soluetor in the far fleld reglon for a uniforaty 1lluninaced clrcular eperture. The integral over $\theta$ can be performed lnadiately with a resulting contraction of the sum over besinel funcelons to the alngle term $a=0$. In the liate that $r_{0} \rightarrow \infty$ one 1a left with the integral

$$
E=\int_{0}^{a} J_{0}\left(k_{0} \sin \gamma \rho d p\right) \text {. }
$$

Uelng the relation that

$$
\frac{d}{d x}\left\{x^{n+1} J_{n+1}(x)\right\}-x^{n+1} J_{n}(x) \text {. }
$$

one obtalns, efcer dropplng sone constanew.

$$
E=2 \frac{J_{1}(k \sin \gamma)}{k \cdot \ln \gamma}
$$

The intenstey, defined at $|z|^{2}$ 10 given as

$$
I=I_{0} 4\left[\frac{s_{1}\left(k+a a_{\gamma}\right)}{k \text { vin }}\right]^{2}
$$

where Io 10 the os-axis inteasity $(r)$. This is gust the fandliar Miry patern in the far field.

\section{Festat orfmuction}

The deffraction pactern io now conetdurad for finte $5_{0}$. This raquires the seatral evaluation of Eq. (9). We now reseriet the rentalng discteston to the intensity on the axis $r_{c}$. In this ceet, $r=0$ and the ooly Based function that ranins fo ano. At this potne, we zcouve the sesurption that the radiug of the aperture to a conatent and conasdar ft - Eunction of 0 . Under shese conditions, Eq. (9) ary be writeen in the for

$$
\begin{aligned}
E & =\int_{0}^{2 \pi} d \theta \int_{0}^{\frac{2 \pi(\theta)}{2 x_{0}}} e^{2 \pi} d x \\
& =\int_{0}^{2 \pi}\left[e^{1 / 2}(\theta) / 2 x_{0}-1\right] d \theta .
\end{aligned}
$$




\section{v. NONSYMETPIC GPERTURES}

He now assume an arbltarary perturbation on the radius of the aperture. The perturbation can be expressed in the general Fourler form

$$
a(\theta)=a\left[1+\sum_{m} c_{m} \sin (m \theta)\right]
$$

where a 1s the average radius of the aperture. Definiog the Freanel rumber of the apertuce as

$$
\mathrm{N}=\frac{\mathrm{a}^{2}}{\lambda \mathrm{r}_{0}},
$$

Eq. (14) way be writsen in the form

$$
E=\int_{0}^{2 \pi}\left[e^{1 m\left(1+\varepsilon \varepsilon_{m} \sin (m \theta)^{2}\right.}-1\right] d \theta \text {. }
$$

We now aavure that al2 $\varepsilon_{m}<1$ and expand the bracket In the exponent. Using the Bessel function Identicy in Eq. (8), we obtain

$$
E=\int_{0}^{2 \pi}\left[e^{1 m K} \sum_{n} \pi J_{n}\left(2 \pi \varepsilon_{m}\right) e^{\ln \theta}-1\right]_{(17)} d \theta
$$

where the product is eaken over all Fourler components. Perforaing the integration ylelds the result that the electric field is given by

$$
E=\left\lfloor e^{1 \mathrm{MH}} \pi J_{0}\left(2 m i c_{m}\right)-1\right\} \text {. }
$$

Reinserting the appropriate constants and defining $\bar{I}$ to be che average bean incenetty across the spezcure. the Intensity on axis is given by

$$
I=\bar{I}\left\{\left[\left.\pi_{0}^{J}\left(2 \pi N c_{0}\right)\right|^{2}+1-\left.2 \pi J_{0}(2 \pi N c) \cos M \pi\right|_{\text {(19) }}\right.\right.
$$

Which 18 the desired result.

In the linte of parfectly circular sperture, $c_{m}-0$ and Eq. (29) becomes

$$
I=4 \bar{I} \operatorname{aln}^{2} \frac{\mu \mathrm{n}}{2} \text {. }
$$

Eq. (20) ylelds thit fendisar teavit that the intenoity alont the axis in the frasne: reston of diffraction othlbits waxien and ainten at odd and even Eresnel nubbers, respectively. This is the characteristic behovior of the central diffraction "spike" resultint trom andforaly 1liuninated clrcular aperture.

In ofder to inveatigate the effects of a noncircular aperture, we assume $2 \pi \mathrm{Hc}>1$. Vatne the asympotic fort for $3_{0}(x)$. Eq. (19) becones
$I=\bar{I}\left[1-\pi \sqrt{\frac{4}{\pi N \varepsilon_{m}}} \cos \left(2 \pi \varepsilon_{m}-\pi / 4\right) \cos N \pi\right]_{(21)}$ One observes in Eq. (2L) that as $\mathrm{IN}_{\varepsilon_{\mathrm{m}}} \rightarrow \infty$, the osc1llatory behavior of the on-axis intensity vanishes. Frow the standpoint of self-focusing, one wants to animise any peske in rhe intensicy ahove che average. For perfect ilrcular aywetry, Eq. (20) Ind1cates that this peak value can be four times the average value. The awount of reciuction, resulting frow any one Fourter cosponcnt, can be estimated frov Rq. (2I) and is Indicated in Fig. 2.

Prom the figure, It is obvious that a signif1cant reduction in the intensity variation can be echieved with an fregularity of an awount $c_{-}=\frac{10}{\text { IN }}$ $\approx \frac{3}{N^{\circ}}$ At a Presnel nuber of 20 , this amounts to a vartation in radius of 15 percent, a value easfly achleved in prestlce. In orter to reduce the varlation of Intansity from 66 percent to 20 percent, one

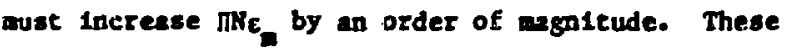
resulte are amarized in $\mathrm{FIg}$. 2 where we have ple:ted the value of $I_{\text {max }} \sqrt{I}$ veraus nomalized Fresnel nwber IHe. Since the effeci of any fintec applizude Fourler components on the cac111arory belavior of the Intensity enters an a product of reduction factore, it is obvious that the nore irregular the perturbation, the wore the oscliletory interlatey behavtor is dininished. It should be noted that each Fourier component of the Irregularity provtdes the sane reduction facent.

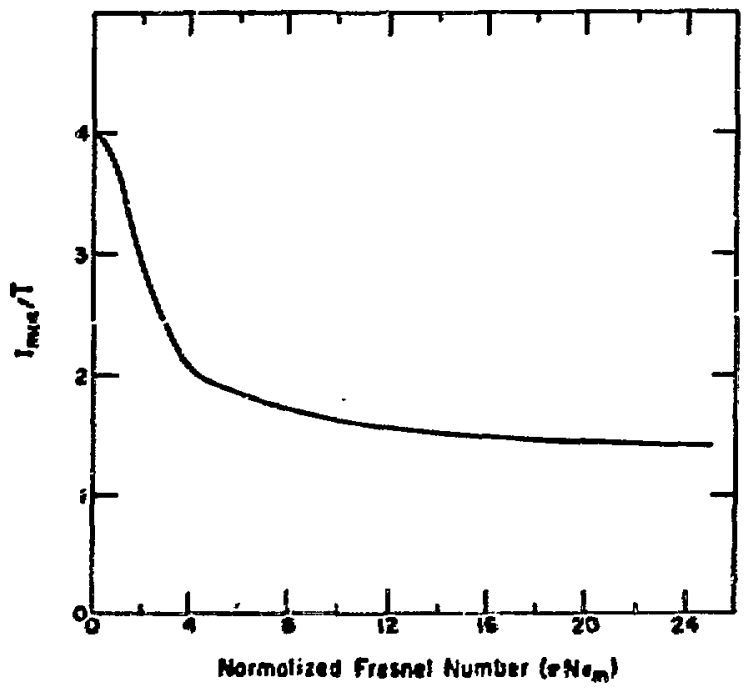

F45. 2. On-axis Lntensity deperdence so a function of Frencl nubet and pereurbacion apilcude. 
The oscillatory variation of the on-axis intenaity is largest for a uniformly 1lluminated aperture. One case of a nonuiform aperture 11lunination is now considered.

vi. GAUSSLAN ILLIMIHATION

For this case, the source distribution is assumed to be of the form

$$
F(p, \theta)=e^{-\frac{\rho^{2}}{b^{2}}}
$$

Insering this form into $\mathrm{Eg}$. (9) ylelds the previous results with $N$, replaced by

$$
N \rightarrow N+\frac{1}{n} \frac{a^{2}}{b^{2}}
$$

In the limt of the circular aperture, Bq. (20) becomes

$$
I \times\left\{\left[1-e^{\left.-a^{2} / b^{2}\right\}^{2}}+4 e^{-a^{2} / b^{2}} \sin ^{2} \frac{N \pi}{2}\right\} \cdot(24)\right.
$$
As $\mathrm{a}^{2} / \mathrm{t}^{2} \rightarrow 0$, the uniform 11lumination result is recovered. In the opposite 11mit, $a^{2} / b^{2} \rightarrow \infty$, the beas doesn't "see" the aperture and the dependence on $N$ van1shes.

1 The 1imtt of a noncircular aperture 1s obtained by the substitution

$$
J_{0}(x) \rightarrow e^{-a^{2} / b^{2}} J_{0}(x)
$$

in Egs. (19) and (21). The result is that the value of IINE Is replaced by

$$
\pi \mathrm{IH} \epsilon \rightarrow \pi N \epsilon e^{2 \mathrm{a}^{2} / \mathrm{b}^{2}}
$$

in the expressions derived previously.

RUPERENCE

1. Principles of Optics, M. Born and E. Wolf, p. 382 ff, Pergamon Press (1970). 